\title{
Bio-Influenced Self-Healing Mechanism in Concrete and Its Testing: A Review
}

\author{
Albert A. Griño Jr. *, Ma. Klarissa M. Daly and Jason Maximino C. Ongpeng \\ Department of Civil Engineering, De La Salle University, 2401 Taft Avenue, Manila 1004, Philippines; \\ ma.klarissa.martinez@dlsu.edu.ph (M.K.M.D.); jason.ongpeng@dlsu.edu.ph (J.M.C.O.) \\ * Correspondence: albert_grinojr@dlsu.edu.ph
}

Received: 3 June 2020; Accepted: 30 June 2020; Published: 27 July 2020

\begin{abstract}
The micro-cracks in concrete structures are inevitable due to deterioration throughout their service life through various load combination factors. For that reason, there is a need to repair and maintain the concrete in order to prevent the cracks from propagating, which can decrease the service life of the structure. Using bacteria is one of the possible solutions to repair and heal the cracks. Recent research has shown that, in order to achieve the extended service life of a concrete material, a bio-influenced material, such as bacteria, can be used in order to induce the autonomous self-healing of cracks in concrete. Many researchers are still exploring the potential of bacteria for improving the durability and strength of concrete. However, an inclusive literature review revealed that a self-healing mechanism using bacteria can still be improved. There is an imperative need to conduct a comprehensive review about the recent development of and studies into the self-healing mechanism of concrete, in particular with the behavior of bacteria and its effect on the macro, micro and nanostructure of the concrete matrix. This review article can reveal the potential research gap, predict the emerging research topics and define all existing problems or challenges about the bio-influenced self-healing mechanism in concrete. The latest articles are summarized and analyzed using the Latent Dirichlet Allocation (LDA) in Matlab software in order to come up with a possible area of development and future research into bio-concrete. Microencapsulated technology and acoustic emission could be the emerging methods for evaluating the performance of the bacteria and detecting real time cracks inside the concrete matrix in the future. However, there are still existing problems and challenges regarding the adoption of bacteria in the field of construction industry.
\end{abstract}

Keywords: concrete; self-healing; bacteria; microcapsules; Latent Dirichlet Allocation (LDA)

\section{Introduction}

Concrete is one of the most commonly used materials in the field of construction due to its strength, durability and performance. Generally, the components of concrete include cement, water, fine aggregates, coarse aggregates, additives and other admixtures. By mixing cement and water, the mixture undergoes a chemical process called hydration which can bind all the other components as one, known as concrete. Other cementitious materials, such as fly ash, limestone fines, silica fume and slag cement, are sometimes added directly as a concrete component or blended with cement to become part of the binder for aggregate [1].

The major drawback of concrete is its low tensile strength and brittleness which makes it susceptible and prone to forming micro-cracks. Cracking in concrete can happen at any stage throughout the life span of the material. It is very difficult to detect the micro-cracks in the cementitious matrix due to their size; however, from the external exposure to the environment and types of loadings, it is possible that the micro-cracks might induce the formation of macro-size cracks [2]. The macro-cracks allow water, chlorides ions and other harmful chemicals to infiltrate the pores in concrete, which might affect 
the integrity of the material. Thus, the presence of cracks in the concrete material might compromise the strength and durability of the concrete structure.

Traditionally, concrete material can be repaired through retrofitting in order to prolong the serviceability of a concrete structure. However, the process of retrofitting the concrete is very costly and time consuming. In addition, it is very difficult to repair all the cracks, considering the exact crack location, depth and extent of the damage inside the concrete material. Therefore, a self-healing concrete is needed to repair the cracks in a concrete structure. Previous researchers have shown that only macro-cracks of up to $0.3 \mathrm{~mm}$ can be healed completely through the carbonation of dissolved calcium hydroxide or the hydration of unused cement particles, which can be considered as an autogenous self-healing process [3]. The chemical reaction and mechanism of the carbonation of calcium hydroxide is described in Equation (1).

$$
\mathrm{Ca}(\mathrm{OH})_{2}+\mathrm{CO}_{2} \rightarrow \mathrm{CaCO}_{3}+\mathrm{H}_{2} \mathrm{O}
$$

Bio-concrete is a self-healing technique using bacteria that can fill the cracks in concrete by inducing a calcium carbonate precipitation through biomineralization. The basic mechanism of bacteria-based crack healing happens when the concrete crack occurs. The water will then leak via the formed cracks and the capillary pores of concrete [4]. With the presence of the water and nutrients inside the concrete matrix, the process of the germination of bacteria will take place and the limestone produced can fill the cracks. According to the intensive literature review by Lauer and Slate (1956), they stated that the healing process was discovered first by the French Academy of Science in 1836, which concluded that the self-healing process is the conversion of calcium hydroxide from hydrated cement to calcium carbonate by exposing it to the atmosphere [5]. Malinskii [6] was the first to examine the development of crack-healing via polymeric materials in 1973. In his experiment, crack healing was observed by considering the following parameters: temperature dependence; delamination; the relaxation time of the polyvinyl acetate (polymer). Since then, the process of healing the crack in cement-based products has been intensively used by the researchers to develop various healing agents [7]. Polymers can be seen as one of the promising materials that can be used in the self-healing of concrete. The process of healing in polymers depends on the force interaction between the crack surface and polymeric material, which can result in crack filling and restoration [8]. The substance that is produced and fills the cracks is not enough to fully recover its mechanical properties, due to the lack of adhesion between the crack wall and the polymer [9]. Alternately, Super Absorbent Polymers (SAPs) can be used to carry the water into the cementitious matrix, which might lead to an autogenous self-healing process [10]. In 1974, Ivanov and Polyakov [11] noticed the self-healing process and performance of hydraulic concrete. In 1984, Gray [12] found that, under the condition of water curing, the autogenous healing degree of the interfacial zone between steel fibers and the cement mortar matrix was higher than that of fractured plain mortar or concrete. In 1995, silica fume was added to non-air entrained concrete by Jacobsen et al. [13] in order to produce a self-healing concrete.

The bacteria can be incorporated into the cementitious composites during the mixing process in order to control the crack through bacterial precipitation [14]. In comparison with other conventional healing materials, such as silicone-based polymer and acrylic resin, bacteria are more preferable, since the substances produced, such as calcium carbonate, have good thermal compatibility and outstanding mechanical property with cementitious composites $[15,16]$. Bacterial precipitation can be carried out by applying the bacteria into cementitious matrix using various methods. The three widely used methods are the following: (1) Direct Application; (2) Immobilization; (3) Encapsulation.

The first method is the direct application. For this method, the bacteria can be directly applied to the solution with nutrients or the direct incorporation of bacteria during the mixing process into cementitious matrix. Choi et al. [17] used a solution with urea- $\mathrm{CaCl}_{2}$ and Bacillus Pasteurii for the pre-cracked specimen. He found that the permeability of all the specimens with cracks of decreasing width accelerated the precipitation of bacteria after treating the cementitious matrix with urea- $\mathrm{CaCl}_{2}$. Sangadjia et al. [18] applied the alkaliphilic bacteria with nutrient solution to the cementitious matrix and found that precipitation can fill the cracks in concrete composites, and it would 
be more efficient to use multiple applications of bacterial treatment in order to obtain a substantial bacterial precipitation. Ghosh et al. [19] mentioned that the bacterial precipitation could occupy the pore spaces concrete, which can reduce the total volume of the pores in the matrix, consequently improving the compressive strength.

One of the drawbacks of direct application of the bacteria in a cementitious matrix is the harsh alkaline environment during the concrete mix. It also seems that unprotected bacteria in concrete for a long time period is not a feasible option. The bacteria may not be able to fill and repair the cracks completely if there is no protective cover for the bacteria inside the concrete matrix [20]. In order to ensure the effectiveness and long term survivability of the bacteria, an immobilization method was proposed to apply the bacteria with a protective material in cementitious composites. The efficiency of the self-healing process of immobilized bacteria was more prominent than those with the direct incorporation [21]. Khaliq et al. [22] noticed that the bacteria immobilized in graphite nano-platelets were more substantial in healing the specimens at 3 and 7 days, while bacteria immobilized in light weight aggregates yielded a better result at 14 and 28 days.

The deterioration of the bacterial cells might happen during the process of mixing, hardening and setting in the cementitious matrix [23]. In order to ensure the effectiveness of the self-healing process in bacterial concrete, the process of encapsulation is more preferable than the other previous methods. To protect the bacteria from the harsh environment, suitable carriers can be used. Typically, the function of encapsulation is to protect the bacteria, and ensure that the suitable carriers have no negative effect on the precipitation of bacteria or on the other components of cementitious composites [23]. The healing agent is released in the encapsulation once microcracks occur in the concrete matrix [24].

Autogenous self-healing is one approach that can be used to mitigate the extent of the macrocrack damage. It is imperative to conduct a comprehensive review on recent studies on the behavior of the bacteria and its effect on the macro, micro and nanostructure of the concrete matrix. This research undertaking can fill the potential research gap, emerging research topics and existing problems or challenges about the bio-influenced self-healing mechanism in concrete. The latest articles are summarized and analyzed using the Latent Dirichlet Allocation (LDA) in Matlab software in order to come up with a possible area of development and future research in the field of the construction industry. There were numerous review articles published from 2010 to 2020 about bioconcrete. Tang et al. [25] in 2015 used a comprehensive survey about the assessment methods for self-healing concrete. Four robustness criteria for evaluating self-healing efficiency are proposed and they are as follows: reliability; quality of results; operational considerations; in-situ applicability. Huseien et al. [26] in 2019 made a comprehensive review about the sustainability of nanomaterials based in self-healing concrete. They discussed past development, recent trends, environmental impact, sustainability and the merits and demerits of several methods of self-healing concrete production. The novelty of this review journal is that this is the first report that predicts the converging topics in the future using linear discriminant analysis (LDA) on bio-concrete.

\section{Methodology}

For data analytics, the following steps were taken in order to acquire an updated and high-quality papers: (i) Journal search from ScienceDirect with the following keywords "concrete" AND "self-healing" AND "bacteria"; (ii) Set journal selection criteria (less than ten years); (iii) Refine by Article Type and SCOPUS Q1 Publication Title (iv) Classification based on the results of the LDA in Matlab software; (v) Explore the future research directions in bio-concrete. The reason behind choosing the ScienceDirect as the only database source was that this is the widely recognized database in the field of Construction Engineering, Material Science and Biology. The literature search was carried out and selected only Q1 journals, such as Construction and Building Materials, Cement and Concrete Composites and Cement and Concrete Research, since the authors believe that these are the best resources to obtain new information and findings about bio-concrete. 
In this review, journal articles and review papers were limited to those published less than ten years ago. A total of 168 technical journals were selected and exported as a text data file. The exported text data were sorted using Microsoft Excel to filter the content of abstract and keywords. By using the search and replace function in Excel, the words Abstract and Keywords were removed to clean the raw data. The clean data were used as the input data in Matlab Text Analytics.

This review focused on recent studies into the behavior of the bacteria, its effect on the macro, micro and nanostructure in the concrete matrix and its future direction based on the data analytics in Matlab. By manually reading through articles' abstracts, key scopes, highlights and conclusions, the screening process was reduced to twenty-eight journal reviews and articles in order to come up with a framework structure of integrated approach and summarized data in the form of a table.

It can be seen in Figure 1 that the number of research publications about bacterial concrete has grown remarkably for the past ten years. It is evident that there is a significant increase in the number of articles produced from 2015 to 2019 and it can be concluded that these topics (keywords) are emerging topics in the future and can be considered as a potential research topics. This only proves that there is an increasing interest of researchers and engineers in this emerging field due to their curiosity to discover an innovative material related to bacterial concrete.

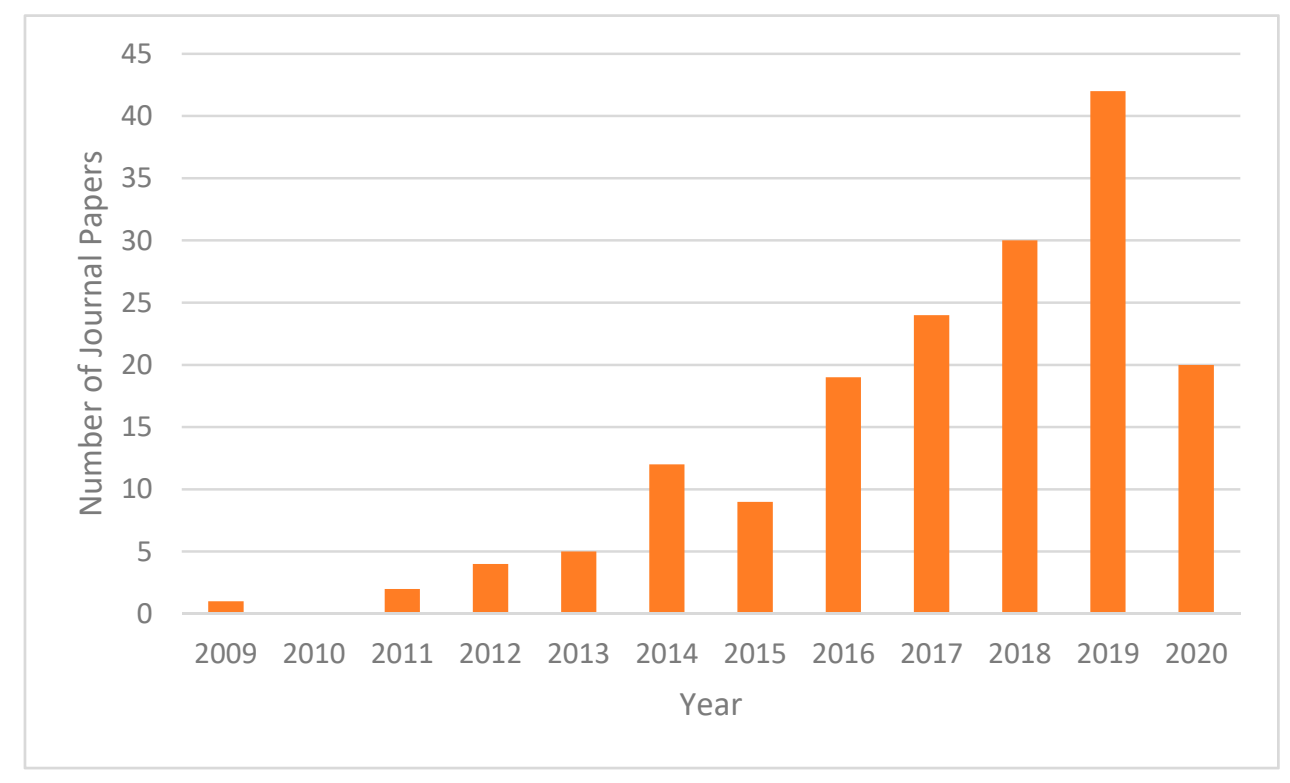

Figure 1. Papers published in ScienceDirect journals on bacterial concrete per year since 2009.

\section{Results and Discussion}

In order to provide an initial overview, this paper presents the searched articles through computer-generated word clouds and Latent Dirichlet allocation (LDA) using MATLAB. This shows the possible families of topics laid upon the availability of related materials. According to LDA, each document is composed of a distinct number of topics and, for each unique topic, there is a discrete distribution of probability for the words generated for all the documents. Similar to the clustering process, the algorithm of LDA iteratively reveals the pattern and probability distribution of the words in each topic. Then, it designates each document a unique topic based on the word distribution and similarity present from the raw data. For this study, the authors combined all the abstract and keywords from the search strings and employed the LDA algorithm of Matlab software. The method for this study is similar to the study made by Burak Gunay et al. [27].

The LDA algorithm was used in order to determine the similarities and reveal the hidden pattern among the journal papers. The summary of the LDA topic results can be seen in Figure 2. The top four words in topic 1 were as follows: scan electron, compressive strength and self-healing agent. This topic can be classified as the evaluation of healing agent/protection to increase compressive strength. 
The second topic contained the following words: carbonate precipitation, calcium carbonate, crack width and concrete structure. This topic can be classified as the quantification of the amount(volume) of calcium carbonate in the crack width. The top two words in topic 3 were: cement mortar; self-healing concrete. This topic was then classified as the closure of the crack through microbial self-healing. The top three words in topic 4 were: mechanical property, cement paste; self-healing crack. This topic was interpreted as the performance of the self-healing efficiency through the crack and mechanical properties. It is also worth mentioning that the main objective of the self healing of concrete using a bacteria is to fill the crack and to increase the compressive strength through calcium carbonate precipitation.

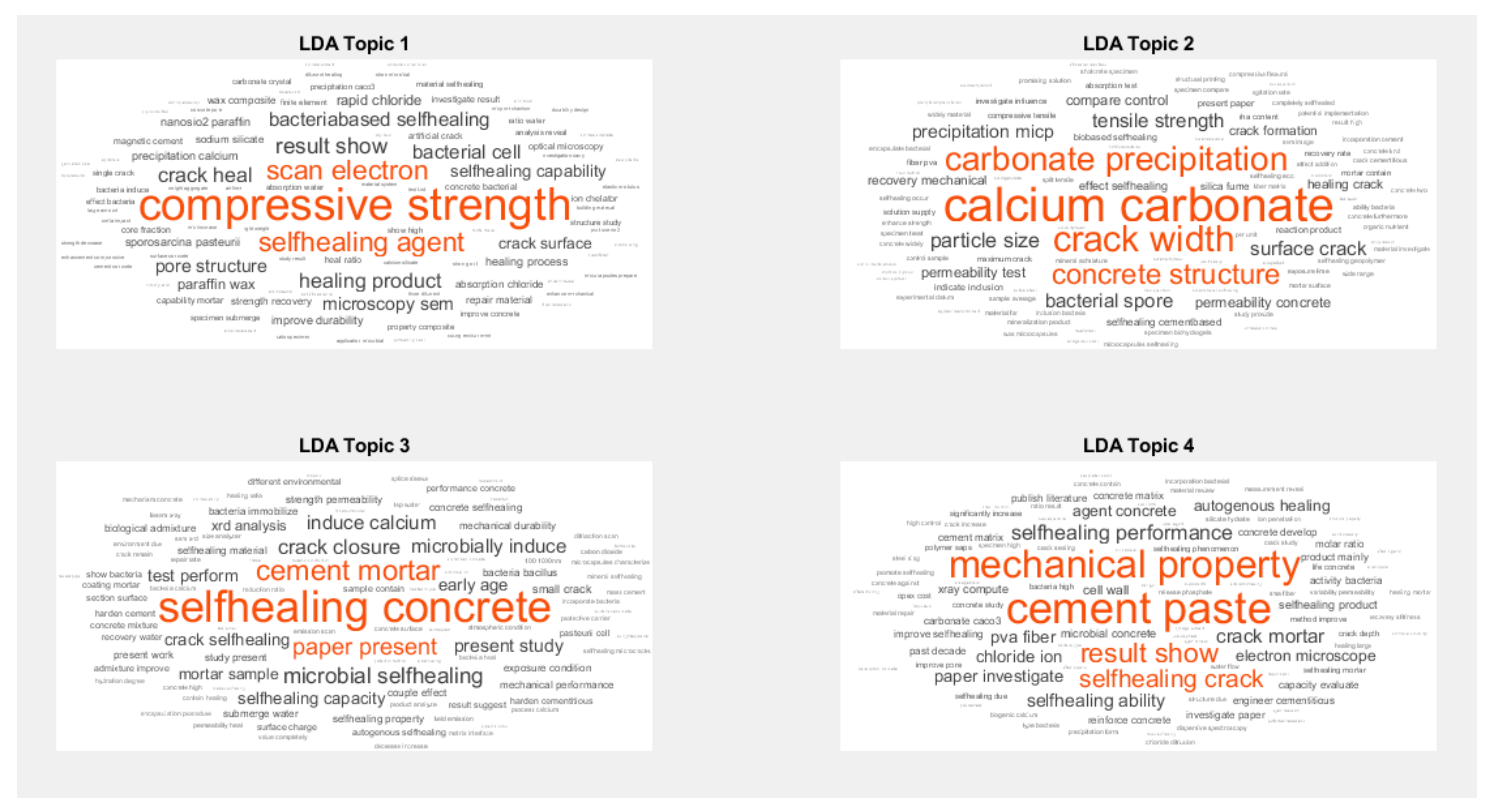

Figure 2. Four LDA topics generated through MATLAB (Abstract + Keywords).

Another method of identifying the underlying topics, aside from the initial four LDA topics above is by generating an additional ten LDA topics, as shown in Figure 3. Since the result of the initial four LDA topics is too general, an additional ten LDA topics were produced in order to generate topics which are more specific and relevant to bio-concrete. The list of related articles is extracted based on the topics generated through Matlab, such as the following: (1)'Repair and self-healing of crack in concrete; (2)'Assessment of durability and permeability of concrete with bacteria; (3)'Novel method to improve the compressive strength property of concrete composite; (4)'Analysis of water reduction/absorption of concrete specimen; (5)'Develop other method, model or system to create cementitious material; (6)'Performance of crack healing; (7)'Efficiency of the self-healing process and the mechanical properties of concrete; (8)'Microbial/bacterial method to induce calcium carbonate precipitation, (9)`Biological cell for cement paste to improve the hydration; (10)'Microcapsule method technology. The last topic might be the emerging topic in the field of bio-concrete, since this method can protect the bacteria from the harsh environment during the concrete mix. This statement is supported by the study made by Kanellopoulos [28] which claimed that, amongst the self-healing techniques developed in the last twenty years, the microencapsulation approach is by far the most studied.

The document topic probabilities can be seen in Figure 4, which shows the probability distribution of the topics from 1 to 10 . It clearly shows that exclusively topics 1 and 2 emerge as the top topics about the self-healing of cracks in concrete with bacteria with a combined percent probability of $28 \%$. Topics 3 and 4 pertain to the compressive strength and water permeability/durability with a combined percentage probability of $21 \%$. Topics 5 to 8 deal with the efficiency of the bacteria to induce calcium carbonate to heal the crack in cementitious materials with a combined probability of $37 \%$. The last 
two topics refer to the microcapsule mechanism technology to infused bacteria in concrete with a $14 \%$ combined probability value.

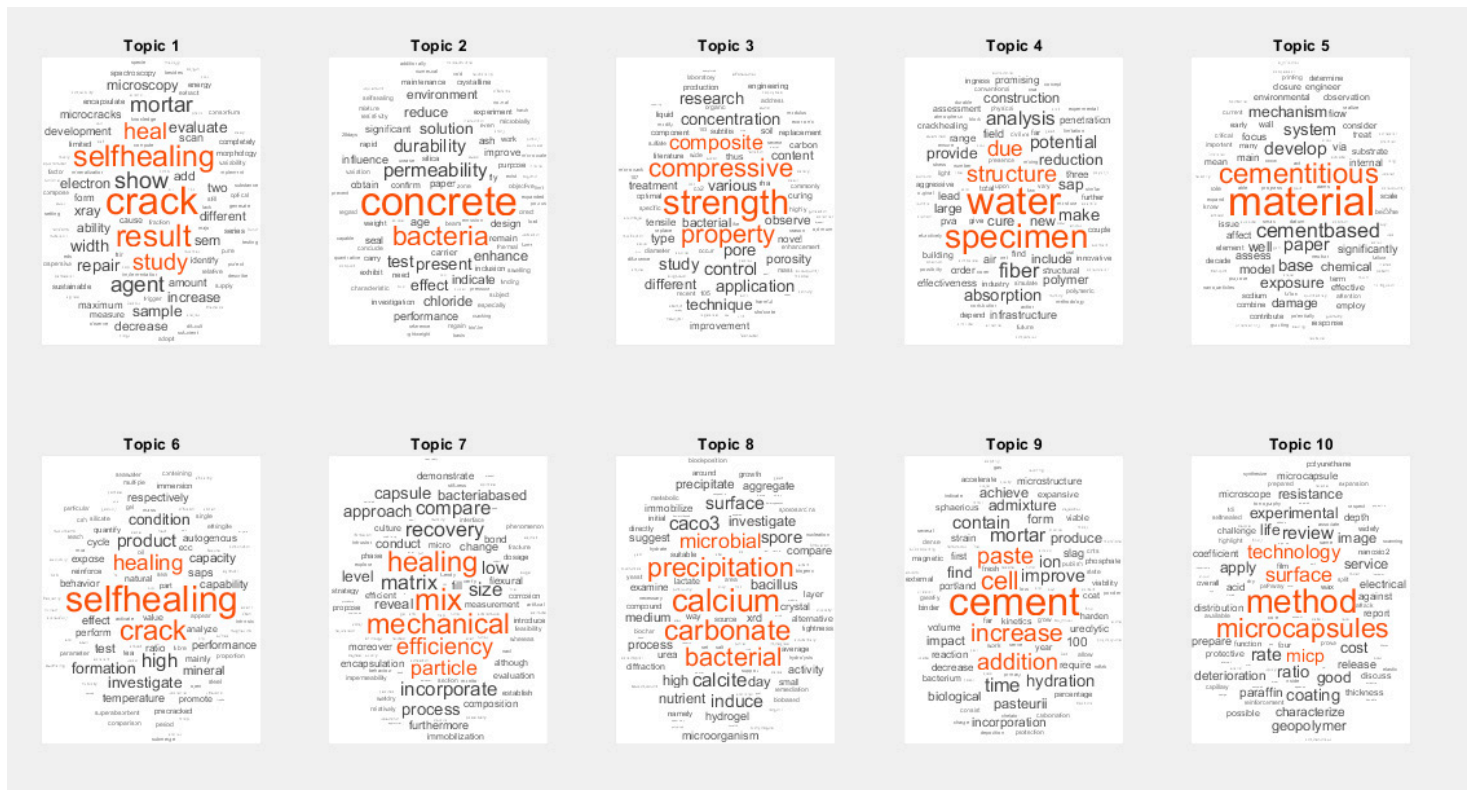

Figure 3. Ten LDA topics generated through MATLAB.

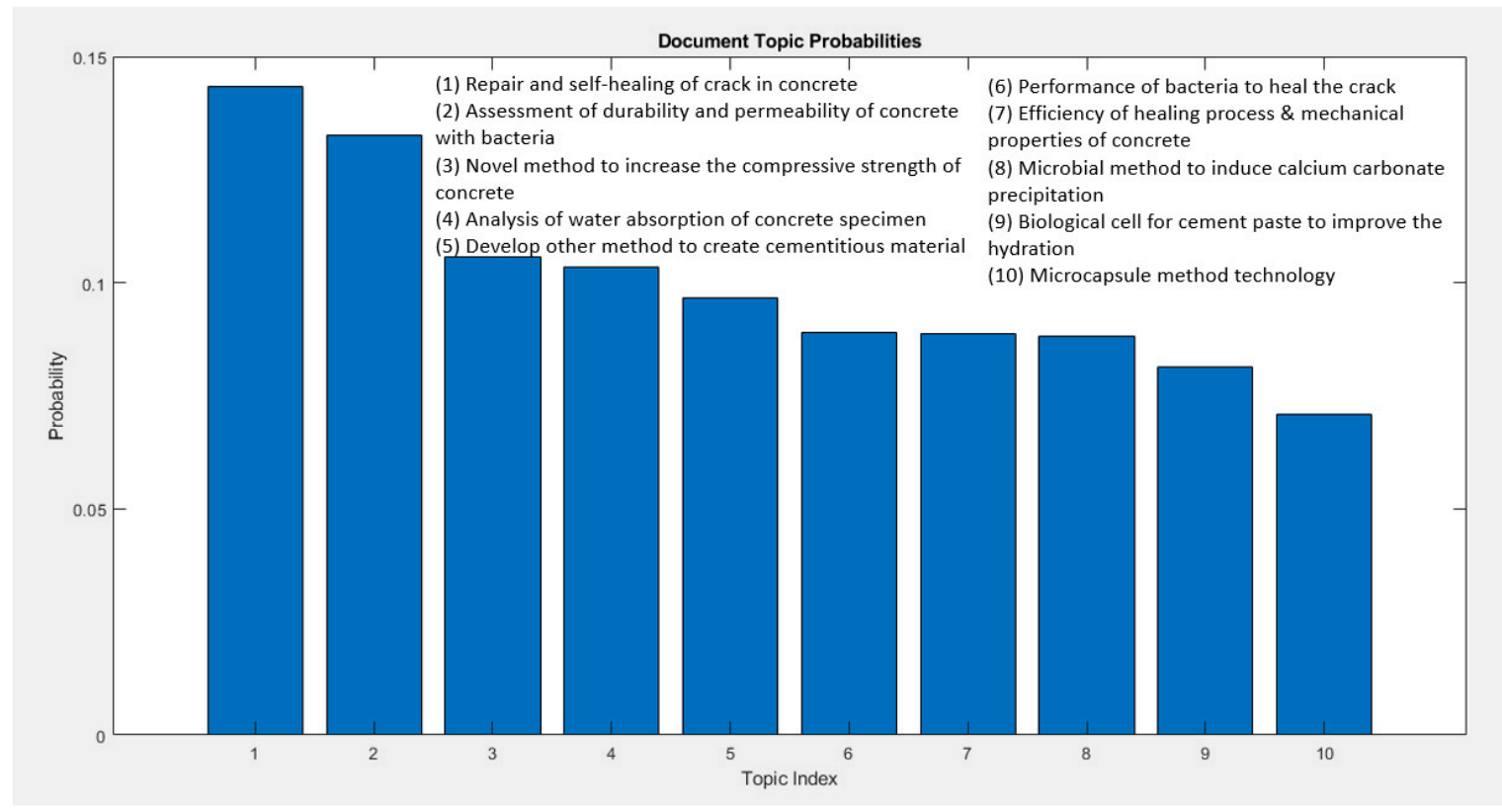

Figure 4. Document topic probabilities of topics 1 to 10 .

As seen in Figure 5, the topic mixtures were generated using topics 1 to 10 with a different combination of topics that can be produced. This graph is relevant and used in this paper in order to generate a new topic and approach related to bio-concrete. Using this figure as a guide, the researcher can generate one possible topic. The value in the y-axis pertains to the number of papers reviewed, while the $x$-axis represents the probability of the topic against the ten topics available. For example, by selecting a point in the ordinate (y-axis) and quantifying the value of probability in the entire row, the researcher can generate a topic such as, "Assessment of durability and permeability of self-healing concrete using other cementitious material". Additionally, it is interesting to note that the combined 
probability of topics 5 to 8 , which are about the "Efficiency of the bacteria to induce calcium carbonate to heal the crack in cementitious material", obtain the highest percentage among the generated topics. Thus, this represents that there is a need to quantify the efficiency of the bacteria to heal the concrete for large scale production and actual application in the construction industry.

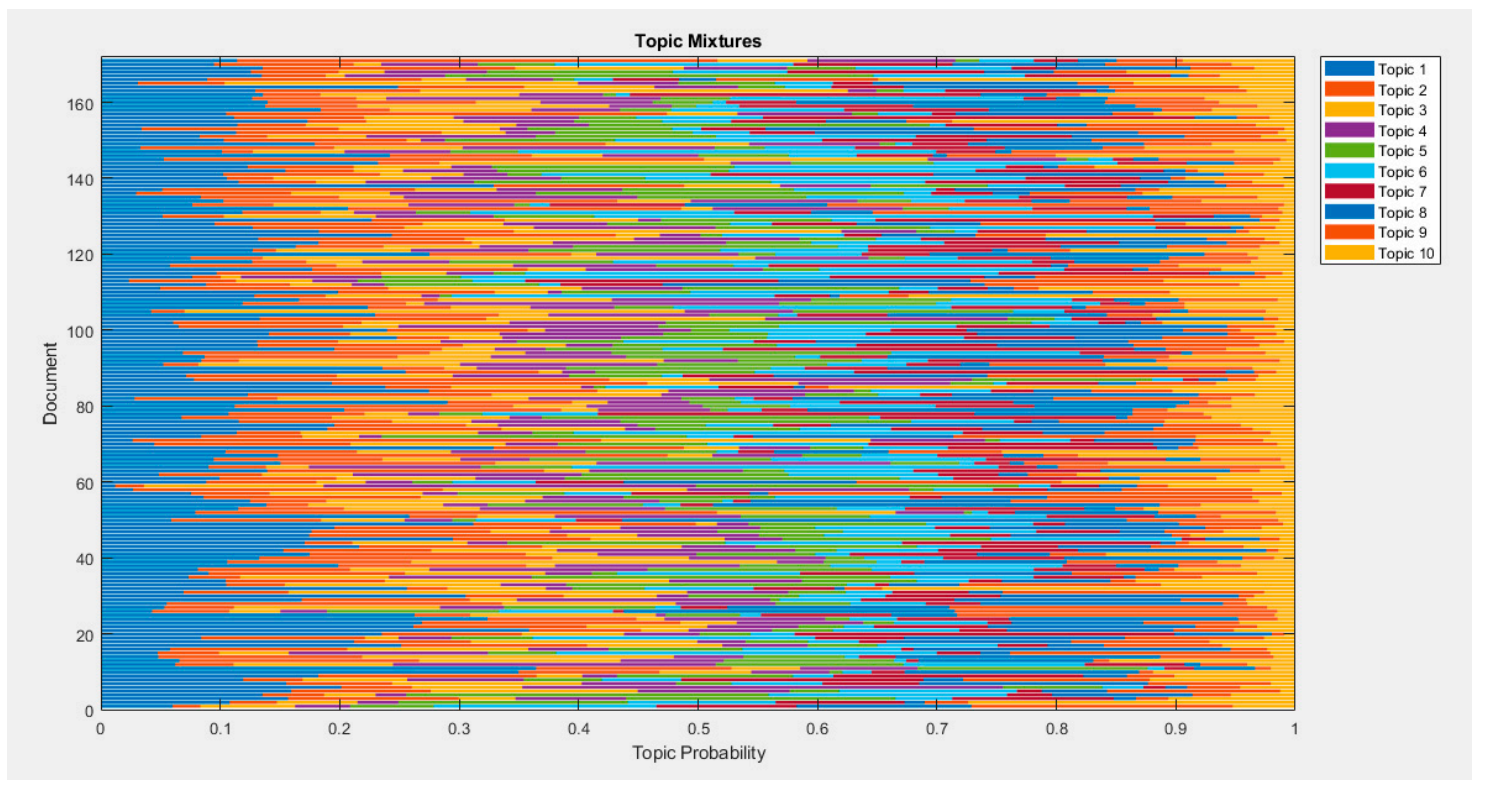

Figure 5. Topic mixtures generated through MATLAB.

\subsection{Scale Level: Macro, Micro and Nano}

In order to establish the efficiency of the bacteria to repair the crack in hardened concrete, structure tests can be carried out at macro, micro and nano scale levels. These include the following tests: Macrostructure; microstructure; nanostructure. The self-healing efficiency of the bacteria in concrete can be evaluated based on the following tests and standard methods, as presented in Table 1.

Table 1. Macro, Micro and Nano Structure Tests.

\begin{tabular}{|c|c|c|}
\hline Scale Level & Test & Standard Methods \\
\hline Macro & $\begin{array}{l}\text { Mechanical Properties(Flexural, Compressive, Split } \\
\text { Tensile, Stiffness and Ultrasonic Pulse Velocity Test) } \\
\text { and Permeability (Chloride Penetration/Permeability, } \\
\text { Porosity, Gas Permeability) }\end{array}$ & $\begin{array}{l}\text { ASTM C39, C1585-13, ASTM } \\
\text { C1202, RILEM 25 PEM (II-6), } \\
\text { JSCE-G571-2003, RILEM } \\
\text { CEMBUREU }\end{array}$ \\
\hline Micro & SEM, FESEM, XRD, EDS & ASTM E986-97, D3906-03, E1508 \\
\hline Nano & Nano-structure measurement & ASTM E2546-07 \\
\hline
\end{tabular}

The macroscopic scale $\left(10^{0}\right)$ is the length scale on which objects or phenomena are large enough to be visible with the naked eye without optical magnifying instruments [29]. The microscopic scale $\left(10^{-6}\right)$ is the scale of an objects smaller than those that can be seen by the naked eye which would require the use of a microscope to view them clearly. The nanoscale $\left(10^{-9}\right)$ refers to the scale length of an object with a range of 1-100 nanometers [30].

The macrostructure test is a procedure wherein the material is evaluated macro-structurally for the quality and consistency of the properties using low or no magnification. The properties under this test are as follows: mechanical and permeability. For the mechanical tests, it includes the following: compressive; flexural; split tensile; ultrasonic pulse velocity; stiffness and toughness tests-while, for permeability, it includes the following: water permeability; chloride penetration; sorptivity; gas permeability tests. 
A microstructure test is a procedure wherein the material is examined through the aid of a microscope or any instruments capable of revealing the morphology and fine structure of a material. It includes the following tests: X-ray diffraction (XRD); Scanning Electron Microscope (SEM); Energy dispersive spectroscopy (EDS); Field Emission Scanning Electron Microscope (FESEM).

The third scale level is the nanostructure test. For this test, properties are evaluated at the nano-scale, which can provide an insight into the behavior of the individual atoms present in the material. This requires powerful scientific instruments that can capture the nanostructure of a material, which is smaller than a micron and larger that an atom.

Concrete is a very complex multiscale material whose behavior at the engineering scale is strongly influenced by the heterogeneous character of its internal material structure [31]. Thus, a multiscale approach is necessary in order to establish the significant role of a bacteria with respect to the cracks in concrete. Multiscale modeling (MM) is defined as the field of solving physical problems that have important features at multiple scales, particularly multiple spatial or temporal scales [32]. According to Zeng et al. [33], there are generally two categories of multiscale modeling strategies or approaches. For the concurrent multiscale method, a combined model is established by linking the several computational methods together [34]. For the sequential multiscale method, a series of hierarchical computational methods are linked in some methods, such as the homogenization method [35].

\subsection{Type of Test: Destructive and Non-Destructive}

Destructive testing can be defined as the process in which the specimen is subjected to a physical destruction in order to evaluate its characteristics and behavior under different types of load. This includes different types of destructive testing methods, such as compression, tension tests, bend tests, Charpy impact tests, Pellini drop weight testing, peel tests, crush testing and pressure and fracture testing. It can be observed in Table 2 that a majority of the researchers conducted the destructive test, similar to the compressive test, in order to evaluate the additional strength improvement of concrete with bacteria. In this way, the percent increase in strength might justify the self-healing process of bacteria inside the concrete matrix. In order to quantify the reliability of the test results in the destructive method, microscopic tests can be done in order to support and validate the result of the self-healing efficiency. The data result that can be generated from the micro-test, such as Scanning electronic microscopy (SEM), can be in the form of an image which shows the formation of calcium carbonate that infiltrates through the cracks in concrete.

Non-destructive testing is a non-invasive technique used by the industry to evaluate the properties of the material. This is typically used for quality testing in order to quantify the amount of damage present in the material. Typically, the local damage detection techniques for non-destructive methods include the following: ultrasonic; acoustic emission; eddy current; impact echo; $x$-ray method; magnetic particle; dye penetrant; rebound hammer.

Acoustic emission has been used over the last decade since it is a very convenient and reliable method as a structural health monitoring tool, compared to other non-destructive methods. One of the advantages of this method is that it can detect early stage cracks based on the release of elastic waves that propagate inside the concrete material. The first scientific application of acoustic emission emerged in the year 1950 when Josef Kaiser conducted a series of tensile tests in metallic materials in order to find the behavior of acoustic emission with respect to the load [36]. The observation he found was named the Kaiser Effect after him, which describes that the material, under load, emits acoustic waves only after a primary load level is exceeded. After Kaiser's experiment, the first extensive research was conducted by Bradford Schofield in 1954 [37]. He carried out experiments in material engineering fields using the process of acoustic emission. He was able to conclude that acoustic emission is not a surface effect but rather a volume effect. Pollock [38] and Esward et al. [39] observed that acoustic emission is different from other nondestructive testing methods in two primary aspects. First, acoustic emission can discover the energy released inside the test material and, secondly, this method is capable 
of finding the dynamic procedures associated with the deterioration of the structures. Grosse [40] mentioned that acoustic emission can be used in detecting the incremental damage of the specimen during the entire loading test without disturbing the property of the material.

Recently, Ongpeng et al. [41] in 2018 conducted an extensive experiment on damage detection in reinforced concrete using acoustic emission with a convex hull algorithm. For this method, they used a convex hull volume algorithm to evaluate the behavior of sound propagating inside the concrete matrix. They found that the convex hull volume can be used to detect the damage until $60 \%$ of the ultimate load of the material. Multiscale modeling can also be applied in acoustic emission test. It was proven in the study made by Ongpeng et al. [42] that acoustic emission test can be used to detect the damage progression in a concrete specimen using computational geometry in a multiscale level. Thus, acoustic emission is a promising method among the non-destructive methods and can be used in order to monitor the propagation of cracks and the performance of bacteria in the concrete.

Aside from acoustic emission, ultrasonic waves can also be used to detect the defects in concrete. Ongpeng et al. [43] used a feed-forward back-propagation artificial neural network (ANN) to determine the significant effect of various ultrasonic parameters on the mechanical load applied. This study can be used as a reference for selecting the most appropriate ultrasonic parameters in assessing the damages in concrete with varying water/cement ratios and reinforcement. For reinforced concrete, Ongpeng et al. [44] showed that the sensitivity of the noncontact ultrasonic test is higher for a concrete structure made by a higher water/cement ratio, where, for the contact ultrasonic test, a lower water/cement ratio concrete structure provides good sensitivity. The loading pattern greatly influenced the generation of higher harmonics in acoustic emission, as reported by Ongpeng et al. [45]. They noticed that the second harmonic generation demonstrates significant changes with incremental load in concrete cubes. Kaur [46] carried out an ultrasonic technique in order to monitor the progression of the healing of fine cracks in concrete. He found that the periodic monitoring of the transmitted pulse throughout the healing period revealed that signal amplitude can be correlated with the extent of healing. Sidiq [47] believed that the most advanced non-destructive test methods for self-healing concrete are mercury intrusion porosimetry and X-ray tomography.

Ultrasound can be defined as an acoustic energy or sound waves with frequencies above $20 \mathrm{kHz}$. For less dense material, such as concrete, an ultrasound frequency range of 50 to $500 \mathrm{kHz}$ is typically used. The process of ultrasonication is commonly perceived as harmful to the growth of bacteria. However, the cells of the bacteria can actually grow in low intensity insonation, due to the ability of the ultrasound to transport the small molecules in solution and its inability to completely remove cells from surfaces [48]. The study made by Jatzwauk et al. In 2001 found that ultrasonication with a frequency of $35 \mathrm{KHz}$ and intensity of $0.66 \mathrm{~W} / \mathrm{cm}^{2}$ for $60 \mathrm{~min}$ alone did not cause any significant damage to the bacteria [49]. Thus, it can be concluded that ultrasonic frequency signal alone does not have any detrimental effect on the cells of bacteria inside the concrete.

Table 2 shows the application methods of bacteria and the corresponding property tests for the twenty-eight journals considered in this study. For the first paper, Jadhav et al. [50] placed the bacteria directly in the concrete mix with geopolymer and found that the crack width of $89 \pm 3 \mu \mathrm{m}$ was sealed completely and the cementitious composites did not cause any significant damage to the bacteria cells. The presence of large pores that are interconnected in the geopolymer was the main reason for the efficient healing capacity and provided the necessary space for the development and reactivation of the bacteria in cementitious composites. Meanwhile, Khaliq et al. [22] concluded that specimens incorporated directly with bacteria did not show any effects in the crack healing of concrete. Sarkar et al. [51] observed that bacterial protein-impregnated mortar samples form nanotube-like structures of silica which fill the micropores of the mortar samples, which enhance the compressive strength and durability of the samples. Xu and Yao [52] assessed the self-healing efficiency of concrete using the nanostructure test. They found that, in the interfacial transition zone, the nano mechanical values were $20 \%$ higher than the precipitates in the outer cell wall, which represented a solid bond between the deposited layer and the concrete matrix. Luhar [53] found that B. sphaericus improved 
the compressive strength of concrete by $30.76 \%$ in 3 days, $46.15 \%$ in 7 days and $32.21 \%$ in 28 days, as compared to conventional concrete. Abo [54] revealed that an increase in one optical density (OD) of the bacterial cells mixed with water produced a 33\% strength improvement in the mortar compressive strength. Durga [55] found that bio-concrete reached a strength improvement of $22 \%$ in compressive strength, $11 \%$ in flexural strength and $16 \%$ in split tensile strength relative to the conventional concrete. Nain [56] found that the compressive strength and split tensile strength of the species Bacillus subtilis, Bacillus megaterium and consortia of both were observed to be higher than $15 \%$ and more, when compared with conventional concrete with M30 concrete in 28 days. Jena [57] revealed that a maximum $32 \%$ increase in compressive strength, a $14 \%$ increase in split tensile strength and a $29 \%$ increase in flexural strength were observed in the specimen, having a bacterial concentration of $10^{5} \mathrm{cells} / \mathrm{mL}$ of water. Chachal [58] found that the inclusion of S. pasteurii in fly ash concrete enhanced the compressive strength and reduced the porosity and permeability of fly ash concrete. From these studies, it can be concluded that the direct incorporation of bacteria has a significant effect on the strength of concrete. However, it can be noted that their results are valid only for a limited period of time. There must be a validation for the survivability and effectiveness of the bacteria over a long period of time. It can be observed that, under the direct incorporation method, almost all of the researchers carried out both destructive and non-destructive tests. The authors usually conducted a non-destructive test, such as the ultrasonic pulse velocity test, in order to determine the dense nature of concrete, and found that certain species of bacteria have a positive effect to the mechanical properties of concrete. It is also interesting to note that the frequency signal of ultrasonic alone does not have any detrimental effect on the viability of bacteria in concrete, since there is an improvement in the mechanical properties.

Multiple protective materials can be used for the immobilization of bacteria in concrete. Limestone powder (LSP), as a protective material was studied by Shaheen et al. [59], iron oxide nano-sized particles (IONPs) were studied by Khushnood et al. [60] and iron oxide nanoparticles were studied by Seifan et al. [61]. Khushnood et al. [60] showed that Bacillus subtilis can improve the compressive strength of concrete and the iron oxide nano-sized particles (IONPs) were considered to be the most effective immobilizers for preserving the bacteria until the generation of cracks followed by the siliceous sand and limestone particles. In addition, the study made by Seifan [61] revealed that the addition of immobilized Bacillus species with iron oxide nanoparticles would increase the compressive strength of concrete. Meanwhile, some researchers have utilized the waste and recycled construction materials as a protective agent, and Manzur et al. [62] are among those who used a crushed brick aggregate. Tittelboom et al. [63] found that thermogravimetric analysis revealed that bacteria with silica gel were able to precipitate $\mathrm{CaCO}_{3}$ crystals inside the cracks and these precipitated crystals filled the cracks. Bundur et al. [64] used an internal nutrient reservoir, which resulted in the growth of vegetative cells without incurring a significant loss in strength. Khaliq et al. [22] revealed that bacteria immobilized in graphite nano platelets gave better results than the concrete specimens pre-cracked at 3 and 7 days, while bacteria immobilized in light-weight aggregates were more effective in samples pre-cracked at 14 and 28 days. Alazhari et al. [65] discovered that self-healing can be attained by coating expanded perlite, as a partial replacement to fine aggregates, by $20 \%$ and calcium acetate was given to obtain a suitable ratio of the spores. Shaheen et al. [59], used the Bacillus subtilis and immobilized the bacteria in the limestone powder (LSP) before mixing it with other concrete components, and found that the compressive strength was improved by $5.75 \%$ at 14 days. It was concluded that limestone powder (LSP) can be considered as a protective material for Bacillus subtilis which can ensure the long term viability of the bacteria in an alkaline environment. $\mathrm{Xu}$ et al. [66] used a porous ceramsite particles as microbial carrier and found out that the regain ratio of compressive strength increased over $20 \%$ with a healing ratio of cracks by $86 \%$. Xu and Wang [67] showed that low-alkali cementitious material made by calcium sulphoaluminate cement with $20 \%$ silica fume can be used as a protective carrier for ureolysis-based bacteria and the regain ratio of compressive strength and water tightness increased by $130 \%$ and $50 \%$ compared with the plain mortar. Bhaskar et al. [68] examined the effect of the two bacteria, such as Sporosarcina ureae and Sporosarcina pasteurii to the compressive strength of 
cementitious composites. They found that the long term performance of the cementitious composites with Sporosarcina pasteurii was $8 \%$ higher than the Sporosarcina ureae. Zhang [69] showed that the specimens incorporated with expanded perlite-immobilized bacteria exhibited the most efficient crack-healing after each healing time. It can be concluded that protective carrier has a specific role for the growth and survivability of bacteria inside the concrete matrix. Additionally, it can be observed that different protective materials have varying efficiencies in healing the cracks in concrete. The protective carrier can be used only for a short-term period but others can also be used for almost a year, as long as there is a nutrient needed by the bacteria to survive. Moreover, the results of the researchers pave the way to develop a self-healing and self-curing concrete with an extended service life, because of the nutrients present within the protective material.

Encapsulation is another way of delivering the healing material into the cementitious composites. For this method, the primary requirement is to have enough strength and resistance as the mixing process takes place and against the internal forces present in the cementitious composites. The healing agent within the capsule should have a low viscosity in order to be released efficiently inside the crack [70]. The healing performance of the encapsulation method is also a function of the following: surface texture, thickness of the shell and capsule diameter [8]. Palin et al. [71] studied the potential of use of encapsulated bacteria in a bead for marine application. They found that the bead showed a crack healing potential because of its capability to swell and induce bacterial precipitation. Liu et al. [72] showed that, compared with unbroken microcapsules, higher calcium precipitation activity (CPA) was achieved by breaking the microcapsule to release the bacterium, suggesting good protection for the encapsulated spores. Wang et al. [73] investigated the self-healing efficiency of encapsulate bacterial with different curing environments. They found that wet/dry cycles was the best curing method in mortar specimens with encapsulated bacteria and the presence of water was an important component for the self-healing process in cementitious composites. Hassan et al. [74] presented that those samples containing alginate beads with bacteria had superior self-healing efficiencies than the control samples without alginate beads. Wang et al. [23] evaluated the self-healing potential of encapsulated bacteria in hydrogels which are used as bacterial carriers and water reservoirs for the uninterrupted healing process in cracks. They found that the precipitation of bacteria can be generated in hydrogels and a crack width of $0.5 \mathrm{~mm}$ can be healed completely. Wang [75] revealed that specimens with bacteria had a more prominent healing ratio compared to those without the bacteria. Thus, the microcapsule method is a promising technology that can be used to protect the bacteria inside the concrete matrix. More research is still needed to further optimize the compatibility of the microcapsule for self-healing efficiency in concrete. These include the following factors: ideal curing environment; specification of the microcapsules; optimize solution components of the nutrients for the bacteria and the ideal time period between the wet and dry cycle. It might be useful to perform numerical modeling for optimization and life cycle analysis of the microencapsulated bacteria in concrete to analyze the energy requirement and sustainability issues of the materials involved.

From the results of the tabulated research methods, it can be concluded that there are different ways to incorporate the bacteria into the concrete matrix and a majority of the tests conducted include the macro and microstructure tests. However, there are a limited number of researchers who carried out tests at nanostructure level. For this type of test, almost all of the researchers conducted a destructive method in order to quantify the strength improvement of the bacteria, relative to the control specimen. Meanwhile, researchers used the non-destructive method in order to validate the self-healing performance of bacteria in cementitious composites. In the future, the process of the non-destructive method, such as acoustic emission, can be used in order to monitor the real-time healing of cracks inside the concrete matrix with the aid of bacteria. 
Table 2. Application methods of bacteria in cementitious composites with protective materials and the corresponding property tests.

\begin{tabular}{|c|c|c|c|c|c|c|c|c|c|}
\hline \multirow{2}{*}{ Method } & \multirow{2}{*}{ Bacterial Strain } & \multirow{2}{*}{ Protective Material } & \multicolumn{3}{|c|}{ Scale Level of Test } & \multicolumn{2}{|c|}{ Type of Test } & \multirow{2}{*}{ Concrete Type } & \multirow{2}{*}{ Ref } \\
\hline & & & Macro & Micro & Nano & D & NDT & & \\
\hline \multirow{10}{*}{ 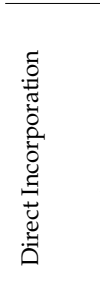 } & Sporosarcina pasteurii & None & & $\mathrm{x}$ & & $\mathrm{x}$ & $\mathrm{x}$ & GPC & [50] \\
\hline & Bacillus subtilis & None & $\mathrm{x}$ & $\mathrm{x}$ & & $\mathrm{x}$ & $\mathrm{x}$ & NSC & [22] \\
\hline & Bacterium BKH1 & None & $\mathrm{x}$ & $\mathrm{x}$ & & $\mathrm{x}$ & $\mathrm{x}$ & NSC & [51] \\
\hline & Bacillus subtilis and sphaericus & None & $\mathrm{x}$ & & & $\mathrm{x}$ & & NSC & [53] \\
\hline & Sporosarcina pasteurii & None & $\mathrm{x}$ & $\mathrm{x}$ & & $\mathrm{x}$ & $\mathrm{x}$ & NSC & [54] \\
\hline & Bacillus subtilis & None & $\mathrm{x}$ & & & $\mathrm{x}$ & $\mathrm{x}$ & NSC & [55] \\
\hline & Bacillus megaterium and subtilis & None & $\mathrm{x}$ & $\mathrm{x}$ & & $\mathrm{x}$ & $\mathrm{x}$ & NSC & [56] \\
\hline & Bacillus subtilis & None & $\mathrm{x}$ & $\mathrm{x}$ & & $\mathrm{x}$ & $\mathrm{x}$ & NSC & [57] \\
\hline & Sporosarcina pasteurii & None & $\mathrm{x}$ & $\mathrm{x}$ & & $\mathrm{x}$ & $\mathrm{x}$ & NSC & [58] \\
\hline & Bacillus cohnii & None & $\mathrm{x}$ & $\mathrm{x}$ & $\mathrm{x}$ & $\mathrm{x}$ & $\mathrm{x}$ & NSC & [33] \\
\hline \multirow{12}{*}{ 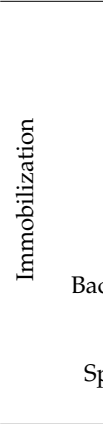 } & Bacillus subtilis & $\begin{array}{l}\text { Iron oxide nano-sized particles (IONPs), limestone powder } \\
\text { and siliceous sand }\end{array}$ & $\mathrm{x}$ & $\mathrm{x}$ & $\mathrm{x}$ & $\mathrm{x}$ & $\mathrm{x}$ & NSC & [60] \\
\hline & Bacillus sphaericus & Silica gel & $\mathrm{x}$ & $\mathrm{x}$ & & $\mathrm{x}$ & $\mathrm{x}$ & NSC & [63] \\
\hline & Urease positive bacterium & Brick aggregate & $\mathrm{x}$ & $\mathrm{x}$ & & $\mathrm{x}$ & $\mathrm{x}$ & NSC & [62] \\
\hline & Bacillus subtilis & LWS and GNP & $\mathrm{x}$ & $\mathrm{x}$ & & $\mathrm{x}$ & $\mathrm{x}$ & NSC & [22] \\
\hline & Sporosarcina pasteurii & Pre-wetted lightweight fine expanded shale aggregates & $\mathrm{x}$ & & & $\mathrm{x}$ & & NSC & [64] \\
\hline & Sporosarcina pasteurii & Ceramsite & $\mathrm{x}$ & & & $\mathrm{x}$ & & NSC & [66] \\
\hline & Bacillus pseudofirmus & Coated expanded perlite & $\mathrm{x}$ & $\mathrm{x}$ & & $\mathrm{x}$ & $\mathrm{x}$ & NSC & [65] \\
\hline & Bacillus cohnii & Expanded perlite & $\mathrm{x}$ & $\mathrm{x}$ & & $\mathrm{x}$ & $\mathrm{x}$ & NSC & [69] \\
\hline & acillus sphaericus and licheniformis & Iron oxide nanoparticle & $\mathrm{x}$ & $\mathrm{x}$ & $\mathrm{x}$ & $\mathrm{x}$ & $\mathrm{x}$ & NSC & [61] \\
\hline & Bacillus subtilis & Limestone powder & $\mathrm{x}$ & $\mathrm{x}$ & & $\mathrm{x}$ & $\mathrm{x}$ & NSC & [59] \\
\hline & Sporosarcina pasteurii & Calcium sulphoaluminate cement & $\mathrm{x}$ & $\mathrm{x}$ & & $\mathrm{x}$ & $\mathrm{x}$ & NSC & [67] \\
\hline & $\begin{array}{l}\text { posarcina ureae and Sporosarcina } \\
\text { pasteurii }\end{array}$ & Zeolite & $\mathrm{x}$ & $\mathrm{x}$ & & $\mathrm{x}$ & $\mathrm{x}$ & NM and FRM & [68] \\
\hline \multirow{6}{*}{ 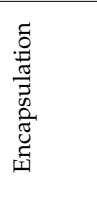 } & Bacillus halmapalus & Bead encapsulating calcium alginate and bacteria & $\mathrm{x}$ & $\mathrm{x}$ & & $\mathrm{x}$ & $\mathrm{x}$ & NM & [71] \\
\hline & Bacillus pseudofirmus & Biomicrocapsule & & $\mathrm{x}$ & & & $\mathrm{x}$ & NSC & [72] \\
\hline & Bacillus sphaericus & Glass tube encapsulating bacteria and silica gel & $\mathrm{x}$ & $\mathrm{x}$ & & $\mathrm{x}$ & $\mathrm{x}$ & NM & [73] \\
\hline & $\begin{array}{l}\text { Bacillus pseudofirmus and } \\
\text { Diaphorobacter nitroreducens }\end{array}$ & Calcium Alginate Beads & $\mathrm{x}$ & $\mathrm{x}$ & & $\mathrm{x}$ & $\mathrm{x}$ & FRC & [74] \\
\hline & $\begin{array}{l}\text { Dlapnorobacter nitroreaucens } \\
\text { Bacillus sphaericus }\end{array}$ & Hydrogel & $\mathrm{x}$ & $\mathrm{x}$ & & $\mathrm{x}$ & $\mathrm{x}$ & NM & [23] \\
\hline & Bacillus sphaericus & Melamine Microcapsule & $\mathrm{x}$ & $\mathrm{x}$ & & $\mathrm{x}$ & $\mathrm{x}$ & $\mathrm{NC}$ & [75] \\
\hline
\end{tabular}

Note: For Type of Test: D—Desctructive and NDT—Non-Destructive. Concrete Type: Normal strength concrete (NSC), Geopolymer Concrete (GPC), Normal Mortar (NM), Fiber Reinforced Mortar (FRM), Fiber Reinforced Concrete (FRC) 
Self-healing technology in concrete is one of the possible solutions to prevent the unnecessary repair and maintenance of concrete structures, as well as to reduce carbon dioxide emissions due to cement production. The demand for concrete as a construction material will increase as the demand for infrastructure development increases. The production of concrete emits a lot of carbon footprints and an energy intensive process. In the long run, concrete material may not be sustainable, due to limited resources and environmental issues. Therefore, there is a need to develop a sustainable concrete material in order to meet demand, as well as to protect the environment.

The market research results show that highways and infrastructure generally, and water retaining structures, would benefit most from self-healing cementitious materials, with reduced maintenance costs over a structure's lifetime, justifying a premium in the capital material cost [76]. At present, there is a lack of large scale production systems and the actual application of bio-concrete in the construction industry. One specific engineering application of bio-concrete is the study conducted by Zhang and Qian in 2020 [77]. They carried out a production system for commercial bio-concrete and they applied it to the side wall of the ship lock. From their study, they found that the cracking of concrete was healed completely after 60 days and the leakage within the cracks was blocked effectively. Therefore, concrete with bacteria is one of the possible solutions to produce a more robust and sustainable material in the field of civil engineering. A self-healing concrete became available in the European market in 2017 as the Green-Basilisk BV company commercialized the Basilisk Self-healing concrete with patent number US8460458B2 [78]. It was also worth mentioning that the company claimed that the service life of a concrete structure can be extended by $30 \%$ using Basilisk Self-healing concrete. This review paper does not cover in-depth patent search comparison and analysis, since it is more centered on research journals concerning bio-concrete from 2010 to 2020.

Reddy et al. [79] studied the cost of the utilization of bacteria in concrete, as compared with the conventional concrete. The cost analysis demonstrated that the price of microbial concrete is 2.3- to 3.9-times higher than the price of conventional concrete with a lower quality [80]. This is one of the main reasons for which this concrete with bacteria is not mass produced and not yet widely used in the construction industry.

The keywords and document analysis, as shown in Figure 6, revealed that compressive strength, calcium carbonate and cementitious composite are the themes receiving much attention in the research of Bacterial Concrete. It is interesting to note that potential research and development (R\&D) would be directed towards filling the research gap about the following topics: (1) Compatibility of bacteria and protective material to concrete; (2) Life Cycle Analysis of bio-concrete; (3) Numerical modeling to optimize the properties and composition of protective material. The majority of the researchers used the Normal Strength Concrete (NSC) as the concrete type for bacteria with 79\%, followed by Normal Mortar (NM) with 15\% and lastly by Geopolymer Concrete (GPC), Fiber Reinforced Mortar (FRM) and Fiber Reinforced Concrete (FRC) with $2 \%$.

There are a lot of researchers working in the domain of concrete as a construction material. Since bacterial concrete is a multidisciplinary topic, it is expected that a lot of researchers outside the domain of civil engineering collaborate with each other. It is expected that the output would be a knowledge-based framework that could serve as a reference in order to improve existing research about bacterial concrete. The outlet direct citation analysis revealed that Construction and Building Materials is considered as the most influential outlet for research on bacterial concrete with $75 \%$ technical journals, followed by Cement and Concrete Composites with $15 \%$ and lastly by Cement and Concrete Research with $10 \%$. Moreover, the most common source of research came from the following countries: China; United Kingdom; Australia; Belgium. 


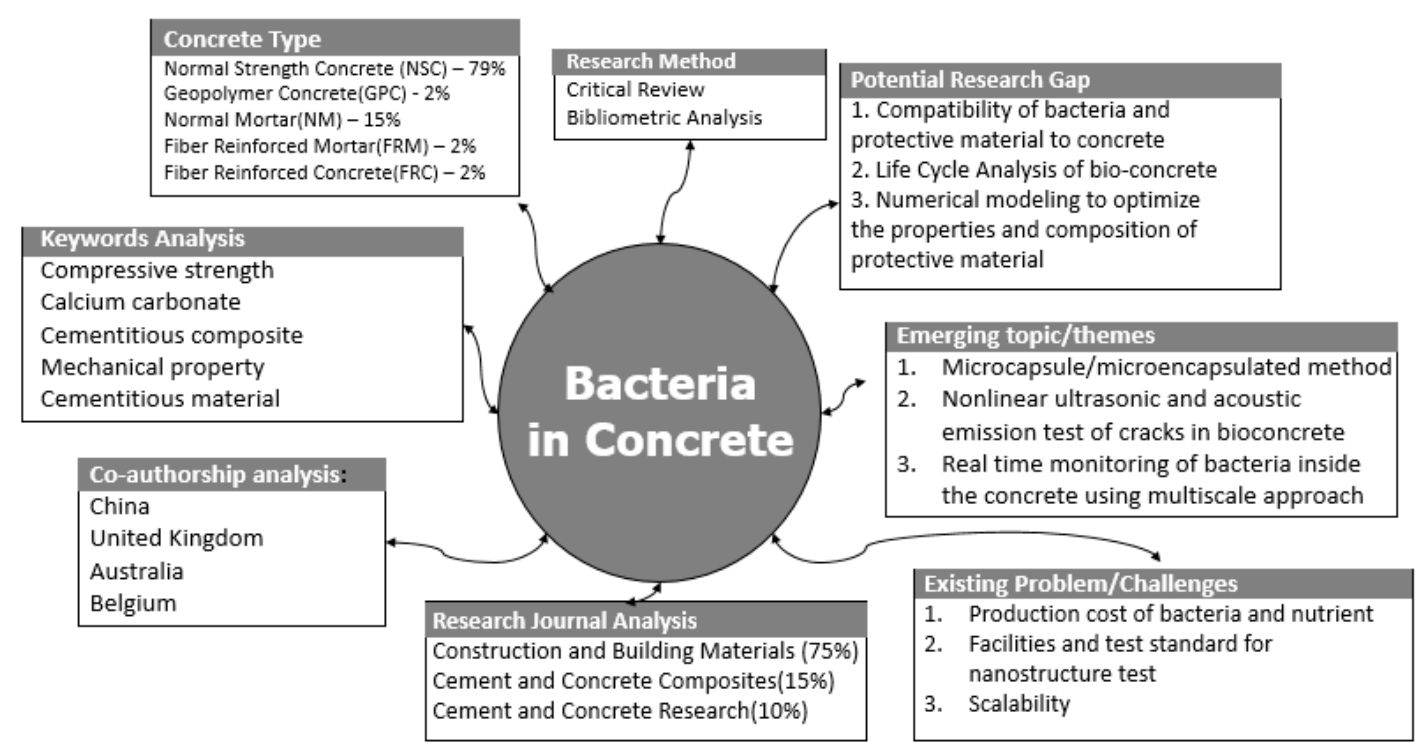

Figure 6. Summary of Findings in Bacterial Concrete.

Several gaps and emerging trends are also highlighted, in which microencapsulated technology and acoustic emission could be the emerging methods for evaluating the performance of the bacteria and detecting real time cracks inside the concrete matrix in the future. The nutrient broth is considered as the major contributor to the cost in the bacterial concrete, covering over $60-75 \%$ of the cost per cubic meter of concrete [79]. Generally researchers used laboratory grade nutrients, which are quite expensive. The overall cost of bio-concrete can be reduced if there is an alternative and cheap nutrient broth sourced locally that is compatible with a bacteria. There are still existing problems and challenges regarding the adoption of bacteria in the field of construction industry. Some of the issues are as follows: (1) Production cost of bacteria and nutrients; (2) Facilities and test standards for nanostructure tests; (3) Scalability from laboratory setup to in situ/actual field application.

\section{Conclusions}

The development of bacterial concrete technology will provide a reference for improving the strength and durability of concrete structures. Microencapsulation is an effective way of protecting and preserving the bacteria for the self-healing process in concrete. This protective material has a specific role for the growth and survivability of bacteria inside the concrete matrix. More research is still needed to further optimize the compatibility of the microcapsule for self-healing efficiency in concrete. A multiscale simulation is needed in order to fully understand the behavior of the bacteria inside the concrete matrix. It might be useful to perform numerical modeling for the optimization and life cycle analysis of the microencapsulated bacteria in concrete to analyze the energy requirement and sustainability issues of the materials involved.

There are still some key issues which remain unaddressed in dealing with bio-concrete. First is the development of the protective materials of the bacteria, which would protect it from harsh environments and dynamic loading present in the field. Second is the production cost of the nutrients needed by the bacteria. The right combination of self-sustaining nutrients and affordability in bacteria would dramatically decrease the total cost of bio-concrete. Nevertheless, bacterial concrete is visualized as providing a more economical and sustainable material in the future.

There are many studies that evaluated the self-healing efficiency of bacteria in the concrete matrix by conducting macrostructure tests. Several of them have carried out the microstructure test in order to validate the width of the cracks, calcium carbonate precipitation and the filling of the cracks. However, there are very few studies that have been carried out at nanostructure level, due to lack of available equipment and reference standards. For the type of test, almost all of the researchers used destructive 
methods in order to quantify the significant contribution of the bacteria to concrete in terms of the compressive strength. Meanwhile, researchers used non-destructive methods in order to validate the performance of concrete with bacteria after the healing process. In the future, the process of non-destructive methods, such as acoustic emission, can be used in the aid of bacteria. In order to fully implement bio-based self-healing concrete, the current technological and technical barriers must be addressed first to make it suitable for widespread construction industry practice.

Author Contributions: Conceptualization, A.A.G.J., M.K.M.D. and J.M.C.O.; methodology, A.A.G.J.; software, M.K.M.D. and J.M.C.O.; validation, J.M.C.O.; formal analysis, A.A.G.J.; investigation, A.A.G.J. and J.M.C.O.; resources, M.K.M.D.; writing—original draft preparation, A.A.G.J.; writing—review and editing, A.A.G.J. and J.M.C.O.; All authors have read and agreed to the published version of the manuscript.

Funding: This research received no external funding.

Acknowledgments: The authors would like to acknowledge the financial support for publication given by the College of Engineering of Adamson University and De La Salle University Civil Engineering Department.

Conflicts of Interest: The authors declare no conflict of interest.

\section{References}

1. Askarian, M.; Fakhretaha Aval, S.; Joshaghani, A. A comprehensive experimental study on the performance of pumice powder in self-compacting concrete (SCC). J. Sustain. Cem. Based Mater. 2019, 7, 340-356. [CrossRef]

2. Yang, Z.; Hollar, J.; He, X.; Shi, X. Laboratory assessment of a self-healing cementitious composite. Transp. Res. Rec. J. Transp. Res. Board 2010, 2142, 9-17. [CrossRef]

3. Van Tittelboom, K.; de Belie, N.; van Loo, D.; Jacobs, P. Self-healing efficiency of cementitious materials containing tubular capsules filled with healing agent. Cem. Concr. Compos. 2011, 33, 497. [CrossRef]

4. Algaifi, H.; Bakar, S.; Sam, A.; Abidin, A. Crack-healing in cementitious material to improve the durability of structures: Review. MATEC Web Conf. 2018, 250, 03005. [CrossRef]

5. Lauer, K.R.; Slate, F.O. Autogenous healing of cement paste. J. Am. Concr. Inst. 1956, 52, $1083-1097$. [CrossRef]

6. Malinskii, Y.M.; Prokopenko, V.V.; Ivanova, N.A.; Kargin, V.A. Investigation of self-healing of cracks in polymers. Polymer Mech. 1970, 6, 382-384. [CrossRef]

7. Davies, R.; Martins, P.; Antonios, K.; Trupti, S. Materials for Life (M4L): Combining multi-scale healing techniques in cementitious materials. In Proceedings of the Fifth International Conference on Self-Healing Materials, Durham, NC, USA, 22-24 June 2015.

8. Joseph, C.; Jefferson, A.D.; Isaacs, B.; Lark, R.; Gardner, D. Experimental investigation of adhesive-based self-healing of cementitious materials. Mag. Concr. Res. 2010, 62, 831-843. [CrossRef]

9. Gilabert, F.A.; Van Tittelboom, K.; Van Stappen, J.; Cnudde, V.; De Belie, N.; Van Paepegem, W. Integral procedure to assess crack filling and mechanical contribution of polymer-based healing agent in encapsulation-based self-healing concrete. Cem. Concr. Compos. 2017, 77 (Suppl. C), 68-80. [CrossRef]

10. Snoeck, D.; Pel, L.; de Belie, N. Autogenous healing in cementitious materials with superabsorbent polymers quantified by means of NMR. Sci. Rep. 2020, 10, 1-6. [CrossRef]

11. Ivanov, F.M.; Polyakov, B.I. Self-healing and durability of hydraulic concrete. Hydrotech. Constr. 1974, 8, 844-849. [CrossRef]

12. Gray, R.J. Autogenous healing of fiber/materix interfacial bond in fiber-reinforced mortar. Cem. Concr. Res. 1984, 14, 315-317. [CrossRef]

13. Jacobsen, S.; Marchand, J.; Hugues, H. Sem observations of the microstructure of frost deteriorated and self-healed concretes. Cem. Concr. Res. 1995, 25, 1781-1790. [CrossRef]

14. Vekariya, M.S.; Pitroda, J. Bacterial concrete: New era for construction industry. Int. J. Eng. Trends Technol. 2013, 4, 4128-4137.

15. Kim, H.K.; Park, S.J.; Han, J.I.; Lee, H.K. Microbially mediated calcium carbonate precipitation on normal and lightweight concrete. Constr. Build. Mater. 2013, 38, 1073-1082. [CrossRef]

16. Seifan, M.; Samani, A.K.; Berenjian, A. Bioconcrete: Next generation of self-healing concrete. Appl. Microbiol. Biotechnol. 2016, 100, 2591-2602. [CrossRef] 
17. Choi, S.; Wang, K.; Wen, Z.; Chu, J. Mortar crack repair using microbial induced calcite precipitation method. Cem. Concr. Compos. 2017, 83, 209-221. [CrossRef]

18. Sangadji, S.; Wiktor, V.; Jonkers, H.M.; Schlangen, E. The Use of alkaliphilic bacteria-based repair solution for porous network concrete healing mechanism. Procedia Eng. 2017, 171, 606-613. [CrossRef]

19. Ghosh, P.; Mandal, S.; Chattopadhyay, B.D.; Pal, S. Use of microorganism to improve the strength of cement mortar. Cem. Concr. Res. 2005, 35, 1980-1983. [CrossRef]

20. Ersan, Y.C.; Silva, F.B.D.; Boon, N.; Verstraete, W.; de Belie, N. Screening of bacteria and concrete compatible protection materials. Constr. Build. Mater. 2015, 88, 196-203. [CrossRef]

21. Li, L.; Zheng, Q.; Li, Z.; Ashour, A.; Han, B. Bacterial technology-enabled cementitious composites: A review. Compos. Struct. 2019, 111170. [CrossRef]

22. Khaliq, W.; Ehsan, M. Crack healing in concrete using various bio influenced self-healing techniques. Constr. Build. Mater. 2016, 102, 349-357. [CrossRef]

23. Wang, J.Y.; Snoeck, D.; Van Vlierberghe, S.; Verstraete, W.; De Belie, N. Application of hydrogel encapsulated carbonate precipitating bacteria for approaching a realistic self-healing in concrete. Constr. Build. Mater. 2014, 68, 110-119. [CrossRef]

24. Vijay, K.; Murmu, M.; Deo, S.V. Bacteria based self-healing concrete-A review. Constr. Build. Mater. 2017, 152, 1008-1014. [CrossRef]

25. Tang, W.; Kardani, O.; Cui, H. Robust evaluation of self-healing efficiency in cementitious materials-A review. Constr. Build. Mater. 2015, 81. [CrossRef]

26. Huseien, G.; Kwok Wei, S.; Mohd Sam, A.R. Sustainability of nanomaterials based self-healing concrete: An all-inclusive insight. J. Build. Eng. 2019, 23. [CrossRef]

27. Gunay, B.; Shen, W.; Newsham, G. Data analytics to improve building performance: A critical review. Autom. Constr. 2019, 97, 96-109. [CrossRef]

28. Kanellopoulos, A.; Giannaros, P.; Al-Tabbaa, A. The effect of varying volume fraction of microcapsules on fresh, mechanical and self-healing properties of mortars. Constr. Build. Mater. 2016, 122, 577-593. [CrossRef]

29. Jaeger, G. What in the (quantum) world is macroscopic? Am. J. Phys. 2014, 82, 896-905. [CrossRef]

30. Hornyak, G.L. Fundamentals of Nanotechnology; Taylor \& Francis Group: Boca Raton, FL, USA, 2009.

31. Cusatis, G.; Rezakhani, R.; Alnaggar, M.; Zhou, X.; Pelessone, D. Multiscale computational models for the simulation of concrete materials and structures. Comput. Model. Concr. Struct. 2014, 1. [CrossRef]

32. Aboudi, J.; Arnold, S.M.; Bednarcyk, B.A. Chapter 7-Multiscale Modeling of Composites. In Micromechanics of Composite Materials; Aboudi, J., Arnold, S.M., Bednarcyk, B.A., Eds.; Butterworth-Heinemann: Oxford, UK, 2013; pp. 447-540. ISBN 9780123970350.

33. Zeng, Q.H.; Yu, A.B.; Lu, G.Q. Multiscale modeling and simulation of polymer nanocomposites. Prog. Polym. Sci. 2008, 33, 191-269. [CrossRef]

34. Li, S.; Xie, H.; Ru, Z.; Gao, M.; Zhang, Z.; Li, G.; Xie, J. A Multiscale Simulation Method and Its Application to Determine the Mechanical Behavior of Heterogeneous Geomaterials. Adv. Mater. Sci. Eng. 2017, 1-12. [CrossRef]

35. Guedes, J.M.; Kikuchi, N. Preprocessing and postprocessing for materials based on the homogenization method with adaptive finite element methods. Comput. Methods Appl. Mech. Eng. 1990, 83, 143-198. [CrossRef]

36. Kaiser, J. Untersuchung über das Auftreten von Geräuschen beim Zugversuch. Ph.D. Thesis, Technische Universität München, München, Germany, 1950.

37. Al-jumaili, S. Damage Assessment in Complex Structures Using Acoustic Emission; Cardiff University: Cardiff, UK, 2016.

38. Pollock, A.A. Acoustic Emission Inspection. In Metal Handbook; ASM International: Metals Park, OH, USA, 1989; Volume 17, pp. 278-294.

39. Esward, T.J.; Theobald, P.D.; Dowson, S.P.; Preston, R.C. An Investigation into the Establishment and Assessment of a Test Facility for the Calibration of Acoustic Emission Sensors; National Physical Laboratory: Teddington, UK, 2002; p. 65.

40. Grosse, C.U.; Reinhardt, H.W.; Finck, F. Signal-based Acoustic Emission techniques in civil engineering. J. Mater. Civ. Eng. 2003, 15, 274-279. [CrossRef]

41. Ongpeng, J.; Oreta, A.; Hirose, S. Monitoring Damage Using Acoustic Emission Source Location and Computational Geometry in Reinforced Concrete Beams. Appl. Sci. 2018, 8, 189. [CrossRef] 
42. Ongpeng, J.M.C.; Oreta, A.W.C.; Hirose, S. Damage Progression in Concrete Using Acoustic Emission Test through Convex Hull Visualization. ACI Mater. J. 2016, 113, 737-744. [CrossRef]

43. Ongpeng, J.; Oreta, A.; Hirose, S. Investigation on the Sensitivity of Ultrasonic Test Applied to Reinforced Concrete Beams Using Neural Network. Appl. Sci. 2018, 8, 405. [CrossRef]

44. Ongpeng, J.; Oreta, A.; Hirose, S. Contact and Noncontact Ultrasonic Nondestructive Test in Reinforced Concrete Beam. Adv. Civ. Eng. 2018. [CrossRef]

45. Ongpeng, J.M.C.; Oreta, A.W.C.; Hirose, S. Effect of load pattern in the generation of higher harmonic amplitude in concrete using nonlinear ultrasonic test. J. Adv. Concr. Technol. 2016, 14, 205-214. [CrossRef]

46. Kaur, N.P.; Majhi, S.; Dhami, N.; Mukherjee, A. Healing Fine Cracks in Concrete with Bacterial Cement for an Advanced Non- destructive Monitoring. Constr. Build. Mater. 2020, 242. [CrossRef]

47. Sidiq, A.; Gravina, R.; Setunge, S.; Giustozzi, F. High-efficiency techniques and micro-structural parameters to evaluate concrete self-healing using X-ray tomography and Mercury Intrusion Porosimetry: A review. Constr. Build. Mater. 2020, 252, 119030. [CrossRef]

48. Pitt, W.G.; Ross, S.A. Ultrasound increases the rate of bacterial cell growth. Biotechnol. Prog. 2003, 19, 1038-1044. [CrossRef] [PubMed]

49. Jatzwauk, L.; Schöne, H.; Pietsch, H. How to improve instrument disinfection by ultrasound. J. Hosp. Infect. 2001, 48 (Suppl. A), S80-S83. [CrossRef]

50. Jadhav, U.; Lahoti, M.; Chen, Z.; Qiu, J.; Cao, B.; Yang, E. Viability of bacterial spores and crack healing in bacteria-containing geopolymer. Constr. Build. Mater. 2018, 169, 716-723. [CrossRef]

51. Sarkar, M.; Chowdhury, T.; Chattopadhyay, B.; Gachhui, R.; Mandal, S. Autonomous bioremediation of a microbial protein (bioremediase) in Pozzolana cementitious composite. J. Mater. Sci. 2014, 49, 4461-4468. [CrossRef]

52. $\mathrm{Xu}, \mathrm{J}$; Y Yoo, W. Multiscale mechanical quantification of self-healing concrete incorporating non-ureolytic bacteria-based healing agent. Cem. Concr. Res. 2014, 64, 1-10. [CrossRef]

53. Luhar, S.; Suthar, G. A review paper on self healing concrete. J. Civ. Eng. Res. 2015, 5. [CrossRef]

54. Abo-El-Enein, S.A.; Ali, A.H.; Talkhan, F.N.; Abdel-Gawwad, H.A. Application of microbial biocementation to improve the physico-mechanical properties of cement mortar. HBRC J. 2013, 9, 36-40. [CrossRef]

55. Durga, C.; Ruben, N.; Madduru, S.R.; Venkatesh, C. Performance studies on rate of self healing in bio concrete. Mater. Today Proc. 2019. [CrossRef]

56. Nain, N.; Surabhi, R.; Yathish, N.V.; Krishnamurthy, V.; Deepa, T.; Tharannum, S. Enhancement in strength parameters of concrete by application of Bacillus bacteria. Constr. Build. Mater. 2019, 202, 904-908. [CrossRef]

57. Jena, S.; Basa, B.; Panda, K.C.; Sahoo, N.K. Impact of Bacillus subtilis bacterium on the properties of concrete. Mater. Today Proc. 2020. [CrossRef]

58. Chahal, N.; Siddique, R.; Rajor, A. Influence of bacteria on the compressive strength, water absorption and rapid chloride permeability of fly ash concrete. Constr. Build. Mater. 2012, 28, 351-356. [CrossRef]

59. Shaheen, N.; Khushnood, R.A.; Ud din, S. Bioimmobilized Limestone Powder for Autonomous Healing of Cementitious Systems: A Feasibility Study. Adv. Mater. Sci. Eng. 2018, 2018, 1-9. [CrossRef]

60. Khushnood, R.A.; Ud din, S.; Shaheen, N.; Ahmad, S.; Zarrar, F. Bio-inspired self-healing cementitious mortar using Bacillus subtilis immobilized on nano-/micro-additives. J. Intell. Mater. Syst. Struct. 2018. [CrossRef]

61. Seifan, M.; Sarmah, A.K.; Samani, A.K.; Ebrahiminezhad, A.; Ghasemi, Y.; Berenjian, A. Mechanical properties of bio self-healing concrete containing immobilized bacteria with iron oxide nanoparticles. Appl. Microbiol. Biotechnol. 2018, 102, 4489-4498. [CrossRef] [PubMed]

62. Manzur, T.; Rahman, F.; Afroz, S.; Huq, R.; Efaz, I. Potential of a Microbiologically Induced Calcite Precipitation Process for Durability Enhancement of Masonry Aggregate Concrete. J. Mater. Civ. Eng. 2016, 29, 04016290. [CrossRef]

63. Tittelboom, K.; Belie, N.; Muynck, W.; Verstraete, W. Use of bacteria to repair cracks in concrete. Cem. Concr. Res. 2013, 157-166. [CrossRef]

64. Bundur, Z.B.; Kirisits, M.J.; Ferron, R.D. Use of pre-wetted lightweight fine expanded shale aggregates as internal nutrient reservoirs for microorganisms in bio-mineralized mortar. Cem. Concr. Compos. 2017, 84, 167-174. [CrossRef]

65. Alazhari, M.; Sharma, T.; Heath, A.; Cooper, R.; Paine, K. Application of expanded perlite encapsulated bacteria and growth media for self-healing concrete. Constr. Build. Mater. 2018, 160, 610-619. [CrossRef] 
66. Xu, J.; Wang, X.; Zuo, J.; Liu, X. Self-Healing of Concrete Cracks by Ceramsite-Loaded Microorganisms. Adv. Mater. Sci. Eng. 2018, 2018, 1-8. [CrossRef]

67. Xu, J.; Wang, X. Self-healing of concrete cracks by use of bacteria-containing low alkali cementitious material. Constr. Build. Mater. 2018, 167, 1-14. [CrossRef]

68. Bhaskar, S.; Anwar Hossain, K.M.; Lachemi, M.; Wolfaardt, G.; Otini Kroukamp, M. Effect of self-healing on strength and durability of zeolite-immobilized bacterial cementitious mortar composites. Cem. Concr. Compos. 2017, 82, 23-33. [CrossRef]

69. Zhang, J.; Liu, Y.; Feng, T.; Zhou, M.; Zhao, L.; Zhou, A.; Li, Z. Immobilizing bacteria in expanded perlite for the crack self-healing in concrete. Constr. Build. Mater. 2017, 148, 610-617. [CrossRef]

70. Han, N.-X.; Xing, F. A comprehensive review of the study and development of microcapsule based self-resilience systems for concrete structures at Shenzhen university. Materials 2016, 10, 2. [CrossRef] [PubMed]

71. Palin, D.; Wiktor, V.; Jonkers, H.M. A bacteria-based bead for possible self-healing marine concrete applications. Smart Mater Struct 2016, 25, 84008. [CrossRef]

72. Liu, B.; Dong, B.; Han, N.; Xing, F.; Deng, X.; Zhu, G. The Feasibility of Waterproof Microcapsule System for Bacteria-Based Self-Healing Cementitious Material 2016. In Proceedings of the 5th International Conference on the Durability of Concrete Structures, Shenzhen, China, 30 June-1 July 2016. [CrossRef]

73. Wang, J.; Van Tittelboom, K.; De Belie, N.; Verstraete, W. Use of silica gel or polyurethane immobilized bacteria for self-healing concrete. Constr. Build. Mater. 2012, 26, 532-540. [CrossRef]

74. Hassan, M.; Milla, J.; Rupnow, T.; Soysal, A. Self-Healing Concrete using Encapsulated Bacterial Spores in a Simulated Hot Subtropical Climate. 2019. Available online: https://digitalcommons.lsu.edu/transet_data/34 (accessed on 25 January 2020).

75. Wang, J.Y.; Soens, H.; Verstraete, W.; De Belie, N. Self-healing concrete by use of microencapsulated bacterial spores. Cem. Concr. Res. 2014, 56, 139-152. [CrossRef]

76. Gardner, D.; Lark, R.; Jefferson, A.; Davies, R. A survey on problems encountered in current concrete construction and the potential benefits of self-healing cementitious materials. Case Stud. Constr. Mater. 2018, 8. [CrossRef]

77. Zhang, X.; Qian, C. Engineering Application of Microbial Self-healing Concrete in Lock Channel Wall. Case Stud. Constr. Mater. 2020, e00398. [CrossRef]

78. Jonkers, H.M. Healing Agent in Cement-Based Materials and Structures, and Process for its Preparation. US Patent 8460458, 11 June 2013.

79. Reddy, V.S.; Seshagiri Rao, M.V.; Sushma, S. Feasibility Study on Bacterial Concrete as an innovative self crack healing system. Int. J. Mod. Trends Eng. Res. 2015, 2, 642-647.

80. Stanaszek-Tomal, E. Bacterial Concrete as a Sustainable Building Material? Sustainability 2020, 12, 696. [CrossRef]

(C) 2020 by the authors. Licensee MDPI, Basel, Switzerland. This article is an open access article distributed under the terms and conditions of the Creative Commons Attribution (CC BY) license (http://creativecommons.org/licenses/by/4.0/). 